\title{
Photoswitchable molecular glue for DNA
}

Chikara Dohno, Shin-nosuke Uno, Kazuhiko Nakatani*

The Institute of Scientific and Industrial Research, Osaka University, Ibaraki 567-0047, Japan

E-mail: nakatani@sanken.osaka-u.ac.jp

\section{$\underline{\text { Supporting Information }}$}

The contents of supporting information:

1) HPLC analysis of photoisomerization of NCDA.

page 2

2) HPLC analysis of photoisomerization of NCDA in the presence of DNA.

page 3

3) UV-vis spectra of NCDA.

page 4

4) $T_{m}$ of duplex DNA in the presence of NCDA.

page 5

5) CSI-tof-MS of NCDA/DNA complex.

page 6

6) Modeling studies of NCDA/DNA complex.

page 7

7) Thermal melting curves of DNA containing two CGG/CGG sites.

page 8

8) Synthesis of NCDA.

page 9-10 
(a)

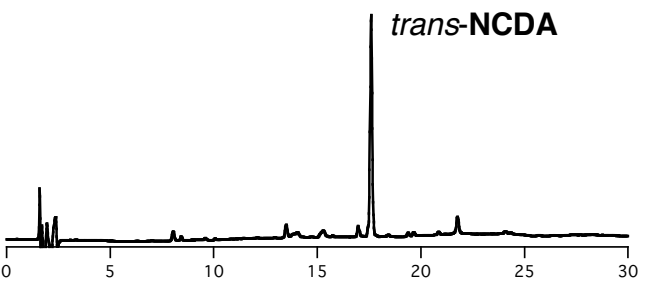

(b)

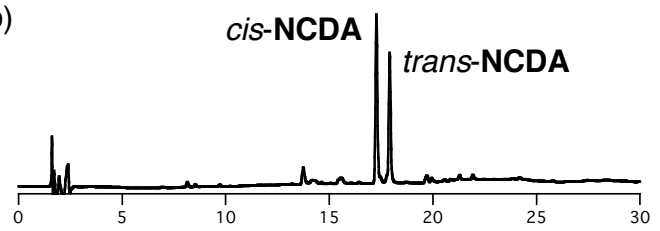

(c)

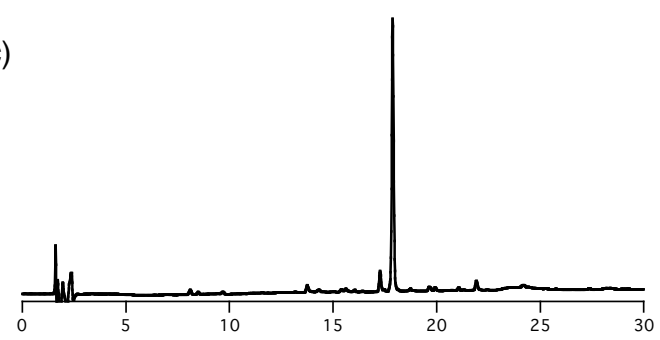

(d)

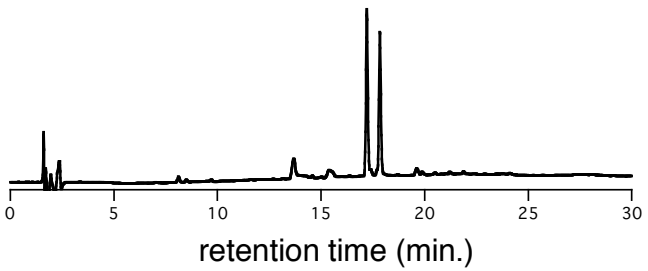

Figure S1. HPLC analysis of the photoisomerization of NCDA. The solution of NCDA (40 $\mu \mathrm{M})$ in $10 \mathrm{mM} \mathrm{Na}$ cacodylate ( $\mathrm{pH} \mathrm{7.0)}$ and $100 \mathrm{mM} \mathrm{NaCl}$ was photoirradiated, and analyzed by HPLC detected by UV absorption at the isosbestic point in the trans to cis isomerization. The peak with longer retention time is attributed to trans-NCDA. The photoisomerization of NCDA proceeded without any significant formation of by-products. Key: (a) Before irradiation; (b) after $360 \mathrm{~nm}$ irradiation for $5 \mathrm{~min}$, (c) subsequent irradiation at $430 \mathrm{~nm}$ for $5 \mathrm{~min}$, (d) subsequent irradiation at $360 \mathrm{~nm}$ for $5 \mathrm{~min}$. 

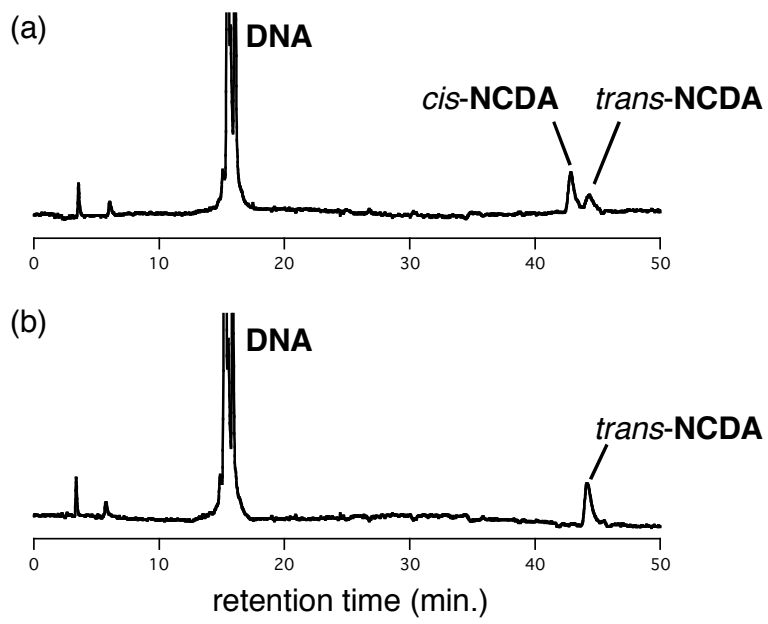

Figure S2. HPLC analysis of the photoisomerization of NCDA in the presence of DNA $1 \cdot 2(4.5$ $\mu \mathrm{M})$. The soluton of NCDA $(18.2 \mu \mathrm{M})$ in $10 \mathrm{mM} \mathrm{Na}$ cacodylate (pH 7.0) and $100 \mathrm{mM} \mathrm{NaCl}$ was photoirradiated, and analyzed by HPLC detected by UV absorption at the isosbestic point. Key: (a) After $360 \mathrm{~nm}$ irradiation for $5 \mathrm{~min}$, (b) subsequent irradiation at $430 \mathrm{~nm}$ for $5 \mathrm{~min}$. 


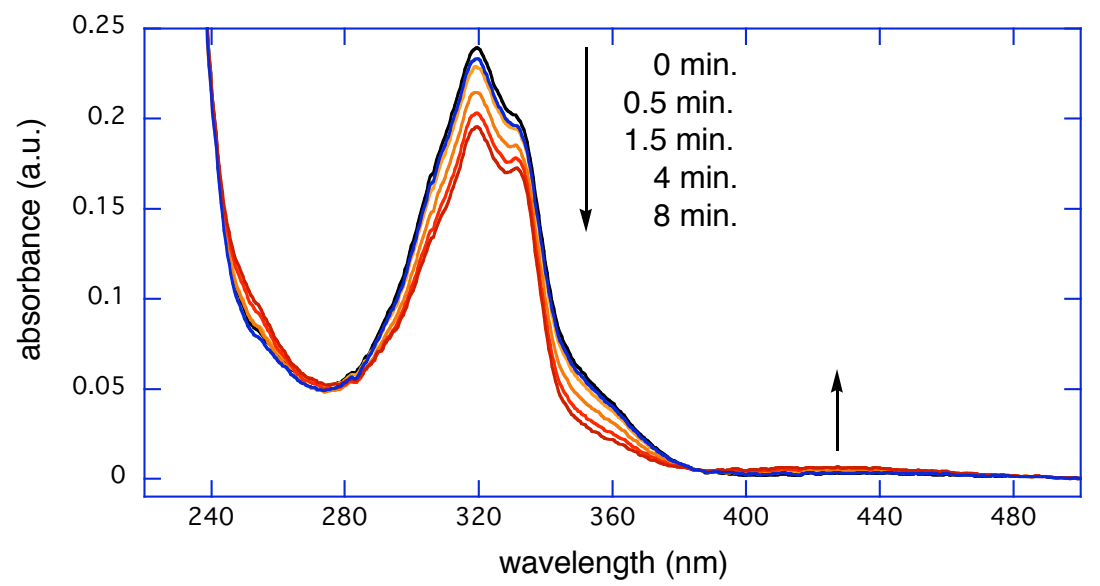

Figure S3. UV-vis spectra NCDA $(6 \mu \mathrm{M})$ in $10 \mathrm{mM} \mathrm{Na}$ cacodylate $(\mathrm{pH} 7.0)$ and $100 \mathrm{mM} \mathrm{NaCl}$. The sample was irradiated with $360 \mathrm{~nm}$ light for the indicated period. Subsequent irradiation at $430 \mathrm{~nm}$ for $3 \mathrm{~min}$ resulted in a recovery of the original spectrum (blue line). 
Table S1. Melting temperature $\left(T_{m} /{ }^{\circ} \mathrm{C}\right)$ of the mismatch-containing duplexes in the presence of NCDA $^{\mathrm{a}}$

\begin{tabular}{|c|c|c|c|c|c|}
\hline \multirow{2}{*}{$X-Y$} & \multirow{2}{*}{$T_{\mathrm{m} 0}^{\mathrm{b}}$} & \multicolumn{2}{|c|}{$+N C D A$} & \multicolumn{2}{|c|}{$+\mathrm{NCDA}, h v$} \\
\hline & & $T_{\mathrm{m} 1} \mathrm{c}$ & $\Delta T_{\mathrm{m} 1}^{\mathrm{d}}$ & $T_{\mathrm{m} 2} \mathrm{e}^{\mathrm{e}}$ & $\Delta T_{\mathrm{m} 2}{ }^{\mathrm{f}}$ \\
\hline A-A & 17.8 & 19.5 & 1.7 & 21.3 & 1.8 \\
\hline A-C & 16.1 & 23.3 & 7.2 & 20.4 & -2.9 \\
\hline $\mathrm{C}-\mathrm{C}$ & 18.2 & 25.7 & 7.4 & 22.7 & -3.0 \\
\hline G-A & 25.7 & 32.0 & 6.3 & 33.4 & 1.4 \\
\hline G-G & 25.6 & 32.7 & 7.1 & 48.0 & 15.2 \\
\hline G-T & 28.3 & 32.0 & 3.7 & 31.5 & -0.5 \\
\hline $\mathrm{T}-\mathrm{C}$ & 18.6 & 27.2 & 8.6 & 23.8 & -3.4 \\
\hline $\mathrm{T}-\mathrm{T}$ & 25.1 & 28.6 & 3.5 & 27.8 & -0.8 \\
\hline $\mathrm{A}-\mathrm{T}$ & 34.3 & 34.5 & -0.2 & 35.2 & 0.7 \\
\hline $\mathrm{G}-\mathrm{C}$ & 40.3 & 38.6 & -1.7 & 40.3 & 1.7 \\
\hline
\end{tabular}

${ }^{a}$ Thermal melting curves were measured for duplex DNA1/2, d(CTA ACX GAA TG)/ d(CAT TCY GTT AG) $(4.54 \mu \mathrm{M})$ in $10 \mathrm{mM}$ sodium cacodylate buffer (pH 7.0) containing $0.1 \mathrm{M} \mathrm{NaCl}$. The absorbance of the sample was monitored at $260 \mathrm{~nm}$ from 2 to $80{ }^{\circ} \mathrm{C}$ with a heating rate of 1 ${ }^{\circ} \mathrm{C} /$ min. $T_{\mathrm{m}}$ values $\left({ }^{\circ} \mathrm{C}\right)$ were calculated by median method. ${ }^{\mathrm{b}} T_{\mathrm{m}}$ values of DNA1/2 in the absence of NCDA. ${ }^{\mathrm{c}} T_{\mathrm{m}}$ values in the presence of NCDA $(18.2 \mu \mathrm{M}) .{ }^{\mathrm{d}} \Delta T_{\mathrm{m} 1}$ is calculated as the difference between $T_{\mathrm{m} 0}$ and $T_{\mathrm{m} 1} \cdot{ }^{\mathrm{e}} T_{\mathrm{m}}$ values in the presence of NCDA after photoirradiation at $360 \mathrm{~nm}$ for 5 min. ${ }^{\mathrm{f}} \Delta T_{\mathrm{m} 2}$ is calculated as the difference between $T_{\mathrm{m} 1}$ and $T_{\mathrm{m} 2}$. 
(a)

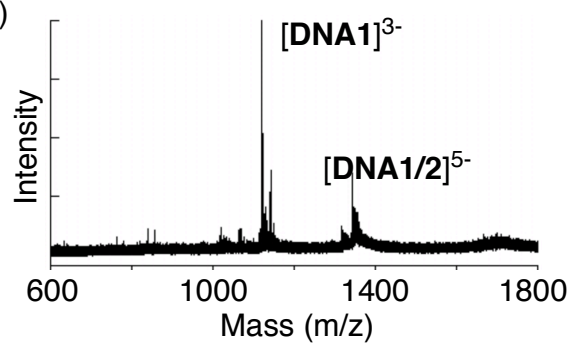

(c)

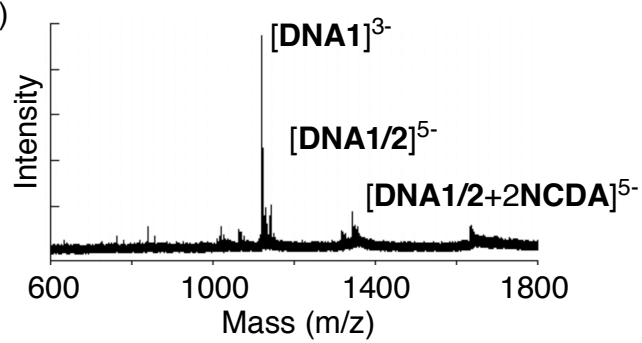

(e)

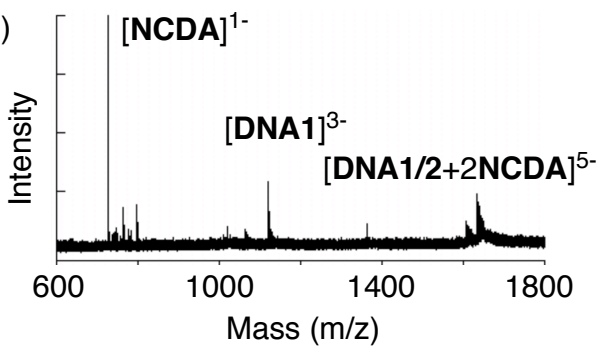

(b)

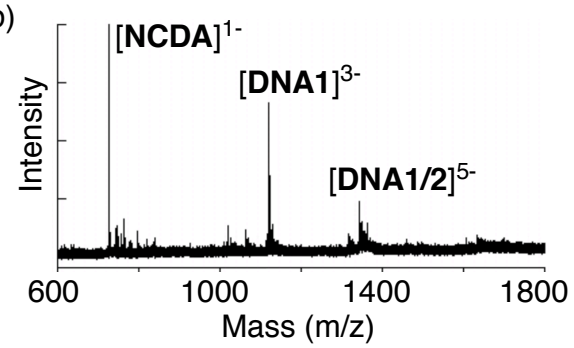

(d)

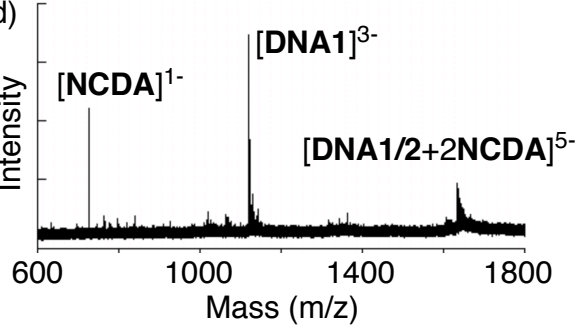

Figure S4. Cold-spray ionization time of flight mass spectra of DNA1/2, 5'-(CTAA CGG AATG)-3'/5'-(CATT CGG TTAG)-3', in the presence of different concentration of NCDA. Samples contained $20 \mu \mathrm{M}$ duplex DNA in 50\% aqueous methanol and ammonium acetate (100 $\mathrm{mM}$ ). The sample was cooled at $-10^{\circ} \mathrm{C}$ during the injection with a flow rate $10 \mu \mathrm{L} / \mathrm{min}^{-1}$. Key: (a) Without NCDA; (b) $40 \mu \mathrm{M}$ NCDA before irradiation; (c) $20 \mu \mathrm{M}$ NCDA after photoirradiation at $360 \mathrm{~nm}$ for $5 \mathrm{~min}$; (d) $40 \mu \mathrm{M}$ NCDA after the photoirradiation for $5 \mathrm{~min}$; (e) $60 \mu \mathrm{M}$ NCDA after the photoirradiation for $5 \mathrm{~min}$. 

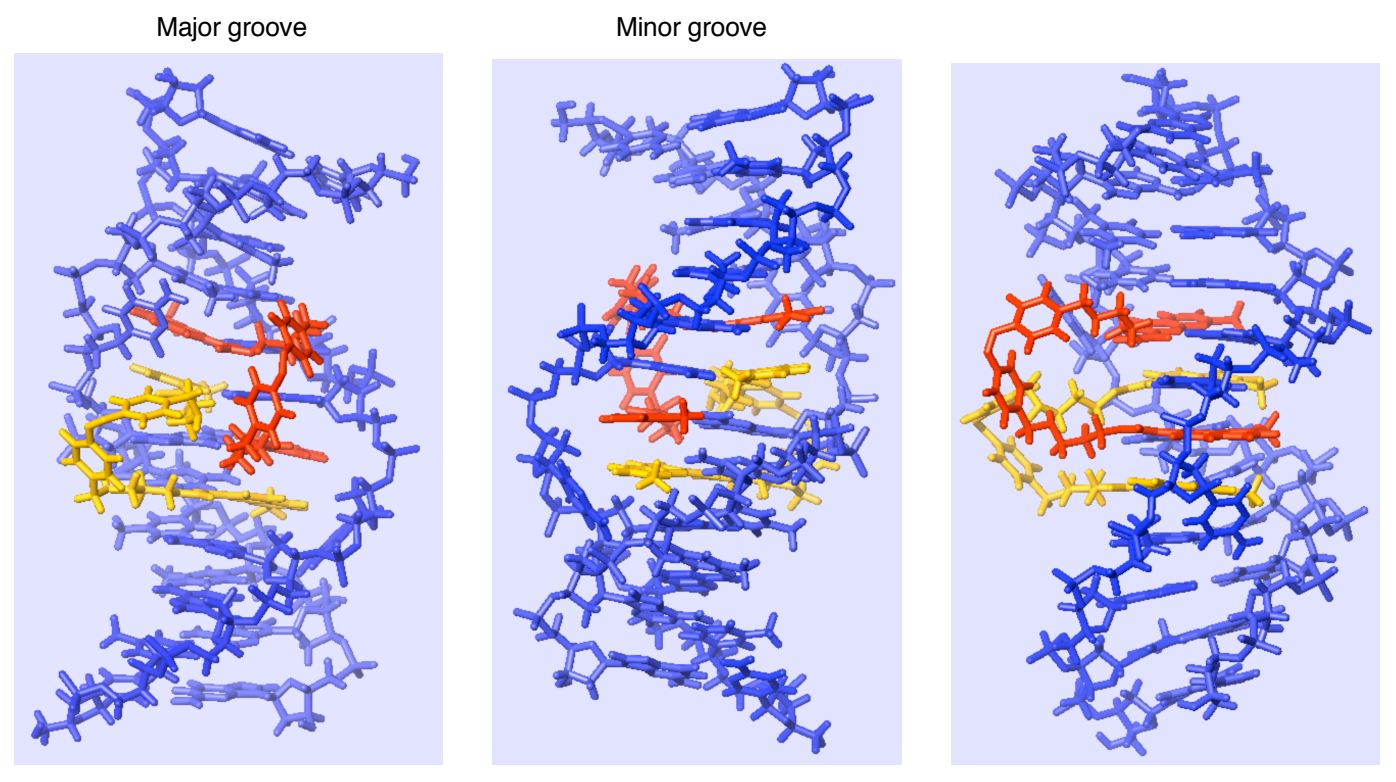

Figure S5. Molecular modeling of the complex between cis-NCDA and 5'-d(CTAACGGAATG)-3'/ 5'-d(CATTCGGTTAG)-3'. The model structures were energy-minimized by use of the AMBER* force field in water with MacroModel Version 9.1. Two NCDA molecules are represented in red and yellow. 


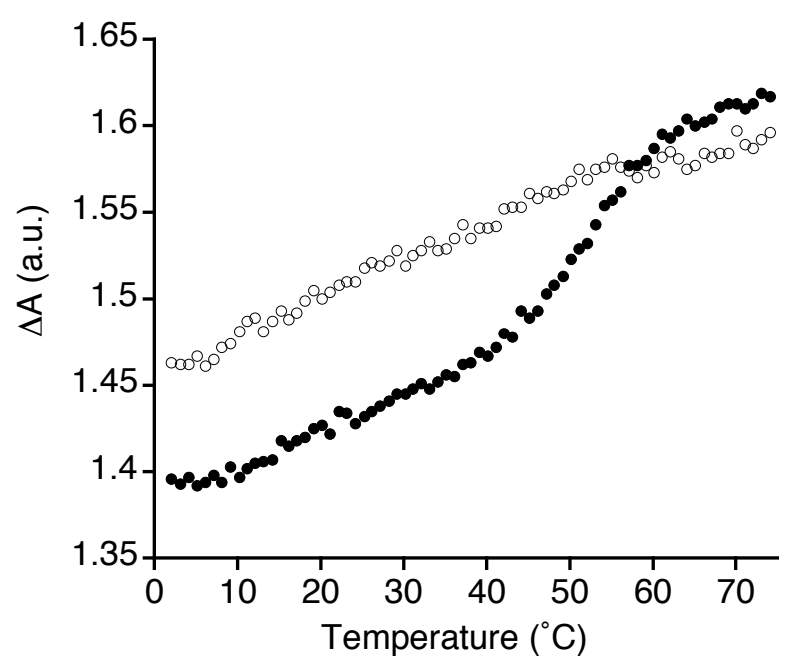

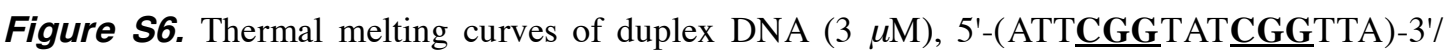
3'-(TAAGGCAAAGGCAAT)-5', in the presence of NCDA $(18 \mu \mathrm{M})$ in $10 \mathrm{mM}$ sodium cacodylate buffer ( $\mathrm{pH}$ 7.0) containing $100 \mathrm{mM} \mathrm{NaCl}$. The absorbance of the sample was monitored at $260 \mathrm{~nm}$ from 2 to $80{ }^{\circ} \mathrm{C}$ with a heating rate of $1{ }^{\circ} \mathrm{C} / \mathrm{min}$. Key: The plots before irradiation (the $T_{\mathrm{m}}$ value cannot be determined due to the unclear transition), open circles; plots after photoirradiation at $360 \mathrm{~nm}$ for $5 \mathrm{~min}, T_{\mathrm{m}}=53^{\circ} \mathrm{C}$, filled circles. 
Scheme $1^{\mathrm{a}}$

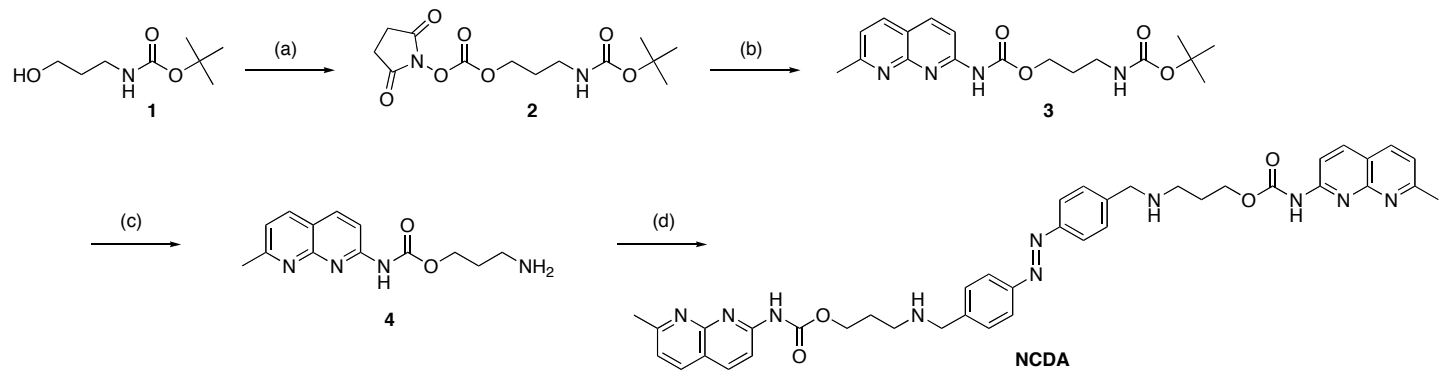

${ }^{a}$ Reagents and conditions: (a) $N, N$ '-disuccinimidyl carbonate, $\mathrm{CH}_{3} \mathrm{CN}, \mathrm{Et}_{3} \mathrm{~N}$, quant.; (b) 2-amino-7-methyl-1,8-naphthyridine, $\mathrm{CH}_{2} \mathrm{Cl}_{2}, \mathrm{Et}_{3} \mathrm{~N}, 72 \%$; (c) $\mathrm{HCl}, \mathrm{AcOEt}, \mathrm{CHCl}_{3}, 90 \%$; (d) 4,4'-Diformylazobenzene, $\mathrm{NaBH}_{3} \mathrm{CN}, \mathrm{AcOH} \mathrm{CHCl}_{3}, \mathrm{MeOH}, 37 \%$.

3-('Boc-amino)propyl $\boldsymbol{N}$-hydroxysuccinimidyl carbonate (2). To a solution of $N$-(3-hydroxypropyl) carbamic acid tert-butyl ester $(1 \mathrm{~mL}, 5.88 \mathrm{mmol})$ in acetonitrile $(16 \mathrm{~mL})$ were added $N, N^{\prime}$-disuccinimidyl carbonate $(2.26 \mathrm{~g}, 8.82 \mathrm{mmol})$ and triethylamine $(2.5 \mathrm{~mL}, 17.9$ $\mathrm{mmol}$ ), and the mixture was stirred at room temperature for $2 \mathrm{~h}$. The reaction mixture was extracted with ethyl acetate, and washed with aqueous $\mathrm{NaHCO}_{3}$ and brine, and dried over $\mathrm{MgSO}_{4}$. Purification by chromatography over silica gel (100:3 of chloroform/methanol) gave 2 (1.84 g, $99 \%)$ as a white powder. ${ }^{1} \mathrm{H} \mathrm{NMR}\left(\mathrm{CDCl}_{3}, 400 \mathrm{MHz}\right) \delta=4.40(\mathrm{t}, J=6.2 \mathrm{~Hz}, 2 \mathrm{H}), 8.11$ (q, $J=6.4$ $\mathrm{Hz}, 2 \mathrm{H}), 2.85$ (s, 4H), $1.96(\mathrm{~m}, 2 \mathrm{H}), 1.44(\mathrm{~s}, 9 \mathrm{H}, \mathrm{NH}) ;{ }^{13} \mathrm{C} \mathrm{NMR}\left(\mathrm{CDCl}_{3}, 100 \mathrm{MHz}\right) \delta=168.7$, $155.9,151.5,79.4,68.9,36.8,28.9,28.3,25.4$.

N-(7-Methyl-[1,8]naphthyridine-2-yl)carbamic acid 3-('Boc-amino)propyl ester (3). To a solution of 2 (940 mg, $2.97 \mathrm{mmol}$ ) and 2-amino-7-methyl-1,8-naphthyridine (431 mg, $2.71 \mathrm{mmol}$ ) in dichloromethane $(20 \mathrm{~mL})$ were added triethylamine $(0.56 \mathrm{~mL}, 4.02 \mathrm{mmol})$, and the mixture was stirred at $50^{\circ} \mathrm{C}$ for $5 \mathrm{~h}$. The reaction mixture was extracted with ethyl acetate, and washed with aqueous $\mathrm{NaHCO}_{3}$ and brine, and dried over $\mathrm{MgSO}_{4}$. Purification by chromatography over silica gel (100:2 of chloroform/methanol) gave 3 (705 mg, $1.96 \mathrm{mmol}, 72 \%$ yield) as a colorless foam. ${ }^{1} \mathrm{H} \mathrm{NMR}\left(\mathrm{CDCl}_{3}, 400 \mathrm{MHz}\right) \delta=8.26(\mathrm{~d}, J=8.8 \mathrm{~Hz}, 1 \mathrm{H}), 8.13(\mathrm{~d}, J=9.0 \mathrm{~Hz}, 1 \mathrm{H}), 8.01(\mathrm{~d}, J=8.3$ $\mathrm{Hz}, 1 \mathrm{H}), 7.27(\mathrm{~d}, J=8.3 \mathrm{~Hz}, 1 \mathrm{H}), 7.81(\mathrm{br}, 1 \mathrm{H}, \mathrm{NH}), 4.82(\mathrm{br}, 1 \mathrm{H}), 4.31\left(\mathrm{t}, J=6.2 \mathrm{~Hz}, 2 \mathrm{H}, \mathrm{CH}_{2}\right)$, $3.26\left(\mathrm{q}, J=6.4 \mathrm{~Hz}, 2 \mathrm{H}, \mathrm{CH}_{2}\right), 2.76\left(\mathrm{~s}, 3 \mathrm{H}, \mathrm{CH}_{3}\right), 1.92\left(\mathrm{q}, J=6.5 \mathrm{~Hz}, 2 \mathrm{H}, \mathrm{CH}_{2}\right), 1.45(\mathrm{~s}, 9 \mathrm{H}) ;{ }^{13} \mathrm{C}$ $\operatorname{NMR}\left(\mathrm{CDCl}_{3}, 100 \mathrm{MHz}\right) \delta=163.0,155.9,154.4,153.4,153.3,138.9,136.4,121.2,117.8,112.6$, 79.2, 63.2, 37.1, 29.2, 28.3, 25.4; ESIMS (positive ion mode, methanol) $383.08[\mathrm{M}+\mathrm{Na}]^{+}$.

$\mathrm{N}$-(7-Methyl-[1,8]naphthyridine-2-yl)carbamic acid 3-aminopropyl ester (4). To a solution of 3 (348 mg, $0.967 \mathrm{mmol}$ ) in chloroform (4 mL) were added $4 \mathrm{M}$ hydrogen chloride in ethyl acetate $(1.2 \mathrm{~mL})$, and the mixture was stirred for $1.5 \mathrm{~h}$. The reaction mixture was evaporated, and saturated aqueous $\mathrm{NaHCO}_{3}$ was added. The resulting suspension was extracted with chloroform to 
give 4 (226 mg, $0.87 \mathrm{mmol}, 90 \%$ yield), which was used next reaction without further purification. ${ }^{1} \mathrm{H} \mathrm{NMR}\left(\mathrm{CDCl}_{3}, 400 \mathrm{MHz}\right) \delta=8.26(\mathrm{~d}, 1 \mathrm{H}, J=8.8 \mathrm{~Hz}), 8.12(\mathrm{~d}, 1 \mathrm{H}, J=8.8 \mathrm{~Hz}), 8.00(\mathrm{~d}, 1 \mathrm{H}, J$ $=8.0 \mathrm{~Hz}), 7.27(\mathrm{~d}, 1 \mathrm{H}, J=8.0 \mathrm{~Hz}), 4.33(\mathrm{t}, 2 \mathrm{H}, J=6.2 \mathrm{~Hz}), 2.88(\mathrm{~m}, 2 \mathrm{H}), 2.76(\mathrm{~s}, 3 \mathrm{H}), 1.89(\mathrm{~m}$, $2 \mathrm{H})$.

Synthesis of NCDA. 4,4'-Diformylazobenzene $(79.7 \mathrm{mg}, 0.335 \mathrm{mmol})$ and naphthyridine carbamate derivative $4(183 \mathrm{mg}, 0.703 \mathrm{mmol})$ were dissolved in chloroform $(10 \mathrm{~mL})$ and methanol $(5 \mathrm{~mL})$, and the $\mathrm{pH}$ was adjusted to $5-6$ by addition of acetic acid $(50 \mu \mathrm{L})$. The mixture was stirred at room temperature for $15 \mathrm{~min}$. To the stirred solution were added sodium cyanoborohydride $(43 \mathrm{mg}, 0.684 \mathrm{mmol})$ in methanol $(1 \mathrm{~mL})$. The mixture was stirred at room temperature for $2 \mathrm{~h}$. The resulting mixture was extracted with chloroform, and washed with aqueous $\mathrm{NaHCO}_{3}$ and brine, and dried over $\mathrm{MgSO}_{4}$. Purification by chromatography over silica gel (from 100:5 to 100:20 of chloroform/methanol) gave NCDA $(90.6 \mathrm{mg}, 37 \%$ yield) as an orange powder. ${ }^{1} \mathrm{H} \mathrm{NMR}\left(\mathrm{CDCl}_{3}, 400 \mathrm{MHz}\right) \delta=8.25(\mathrm{~d}, J=8.8 \mathrm{~Hz}, 2 \mathrm{H}), 8.11(\mathrm{~d}, J=9.0 \mathrm{~Hz}, 2 \mathrm{H})$, 7.98 (d, $J=8.3 \mathrm{~Hz}, 2 \mathrm{H}), 7.85$ (d, $J=8.3 \mathrm{~Hz}, 4 \mathrm{H}$, Azobenzene), 7.65 (brs, 2H, NH), 7.47 (d, $J=$ $8.3 \mathrm{~Hz}, 4 \mathrm{H}$, Azobenzene), 7.25 (d, 2H), 4.35 (t, $J=6.3 \mathrm{~Hz}, 4 \mathrm{H}, \mathrm{CH}_{2}$ ), 3.90 (s, 4H, Bn), 2.80 (t, $J=$

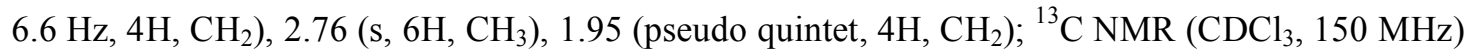
$\delta=163.2,154.7,153.3,153.2,151.8,143.3,139.0,136.4,128.7,122.9,121.3,118.0,112.6,64.0$, 53.6, 45.7, 29.3, 25.6; ESIMS (positive ion mode, methanol) $749.28[\mathrm{M}+\mathrm{Na}]^{+}$; HRMS (FAB) calcd. for $\mathrm{C}_{40} \mathrm{H}_{42} \mathrm{~N}_{10} \mathrm{O}_{4}[\mathrm{M}+\mathrm{H}]^{+} 727.3469$, found 727.3461 . 